\title{
Identifikasi Kesadaran Metakognitif Peserta Didik dalam Pembelajaran Fisika
}

\author{
Rendy Wikrama Wardana ${ }^{1 *}$, Anggun Prihatini ${ }^{2 *}$, M. Hidayat ${ }^{3}$ \\ ${ }^{1}$ Program Studi S2 Pendidikan IPA, Universitas Bengkulu, Bengkulu 38371 \\ ${ }^{2}$ Guru Fisika, MAS Muhamadiyah Talu, Pasaman, Sumatera Barat \\ ${ }^{3}$ Program Studi Pendidikan Fisika, Universitas Jambi, Jambi 36123 \\ *Email: rendywardana@unib.ac.id
}

DOI: https://doi.org/10.33369/pendipa.5.1.1-9

\begin{abstract}
The demands of the 2013 curriculum and limited data on metacognitive awareness in schools encourage researchers to explore and identify the metacognitive awareness of students at on one Islamic high school in the Jambi. The study used mix method research design with an explanatory sequential design. The population was class $X$ in one of Islamic high school Jambi. This Study involved 90 respondents. Sampling uses a purposive sampling technique. Instrument the study was Metacognitive Awareness Questionnaire which was adapted from the Metacognitive Awareness Inventory (MAI). Questionnaire with two indicator: metacognitive knowledge and regulation. Accumulation data with giving a questionnaire MAI on physics learning and interviews with several students to strengthen the questionnaire data. The results showed categorical data regarding metacognitive awareness which is assessed based on metacognitive knowledge and regulation. The category metacognitive knowledge consists of declarative knowledge with a percentage $70 \%$ (good), procedural knowledge 53\% (good), and conditional knowledge $60 \%$ (good). Cognition regulation category consists of planning with a percentage $60 \%$ (good), management information 53\% (good), monitoring of understanding 57\% (good), action strategies (debugging strategies) 53\% (good) and evaluation $73 \%$ (good). Based on the results of study can be interpreted that students could know themselves as students and they are able to overcome their weaknesses or deficiencies in the learning process. For example, students can develop appropriate strategies to solve problems faced in the learning process.
\end{abstract}

Keywords: Identification; Metacognitive Awareness; Students; Learning; Physics.

\begin{abstract}
ABSTRAK
Tuntutan kurikulum 2013 dan terbatasnya data mengenai kesadaran metakognitif di sekolah mendorong peneliti unuk menggali dan mengidentifikasi kesadaran metakognitif siswa di salah satu SMA islam di kota Jambi. Penelitian menggunakan rancangan penelitian Mix Method dengan desain sequential eksplanatori. Populasi penelitian ini adalah siswa kelas X di salah satu SMA islam di kota Jambi dengan jumlah 90 siswa. Pengambilan sampling menggunakan teknik purposive sampling. Instrumen penelitian menggunakan Angket kesadaran metakognitif yang diadaptasi dari angket Metacognitive Awareness Inventory (MAI) dengan dua indikator alat ukur yakni pengetahuan tentang kognisi dan regulasi kognisi. Pengumpulan data dilakukan dengan pemberian angket Metacognitive Awareness Inventory (MAI) pada pembelajaran fisika dan wawancara terhadap beberapa siswa untuk memperkuat data angket. Analisis hasil penelitian dengan menganalisis hasil angket dan wawancara yang selanjutnya dideskripsikan secara kualitatif dan ditarik kesimpulan. Hasil penelitian diperoleh data kategori mengenai kesadaran metakonitif yang dikaji berdasarkan pengetahuan metakognitif dan regulasi kognitif. Kategori pengetahuan metakognitif terdiri dari pengetahuan deklaratif dengan presentase $70 \%$ (baik), pengetahuan prosedural 53\% (baik), dan pengetahuan kondisional 60\% (baik). Kategori Regulasi kognisi terdiri dari perencanaan dengan presentase $60 \%$ (baik), management informasi 53\% (baik), pemantauan terhadap pemahaman 56\% (baik), strategi tindakan (debugging strategies) dengan presentase $53 \%$ dan evaluasi $73 \%$ (baik). Hasil penelitian mengenai kesadaran metakognitif dapat dimaknai bahwa siswa dapat mengetahui tentang diri
\end{abstract}


sebagai pelajar dan mampu menanggulangi kelemahan atau kekuranganya dalam proses belajar. Sebagai contoh siswa dapat menyusun strategi yang tepat untuk menyelesaikan permasalahan-permasalahan yang dihadapi dalam proses pembelajaran

Kata kunci: Identifikasi; Kesadaran Metakognitif; Peserta Didik; Pembelajaran; Fisika.

\section{PENDAHULUAN}

Kurikulum pendidikan di Indonesia selalu mengalami perubahan demi tercapainya tujuan pendidikan Nasional. Pada saat ini, kurikulum yang baru diterapkan di Indonesia adalah Kurikulum 2013. Salah satu kecerdasan yang dibidik pada kurikulum 2013 adalah kecerdasan metakognitif peserta didik. Tuntutan terhadap penguasaan pengetahuan metakognitif disebutkan dalam Permendikbud (2016) bahwa setiap lulusan satuan pendidikan dasar dan menengah memiliki kompetensi pada tiga dimensi yaitu sikap, pengetahuan, dan keterampilan. Pada dimensi pengetahuan kemampuan yang harus dimiliki oleh peserta didik salah satunya adalah pengetahuan metakognitif.

Metakognitif adalah pengetahuan dan kontrol peseta didik terhadap kegiatan belajarnya. Istilah "Metacognitive" pertama kali dikemukakan oleh John Flavel, (1979). Flavell (1979) menjelaskan bahwa metakognitif berperan penting dalam memperoleh informasi, mamahami, membaca, pemecahan masalah serta kontrol terhadap diir sendiri. Menurtut Schraw and Dennison (1994) metakognitif adalah kemampuan untuk merenungkan, memahami, dan mengendalikan pembelajaran seseorang. Wilson and Conyers (2016) mendefenisikan metakognitif sebagai kemampuan untuk memikirikan proses belajar, menyadari faktor faktor yang mempengaruhi kinerja intektual, mengetahui bagaimana, kapan, dimana, dan mengapa menggunkan strategi tertentu, dan kemampuan ini digunakan untuk membantu dan menysuiakan kinerja pembelajaran peserta didik. Menurut Niedringhaus (2010) seorang peserta didik dengan kesadaran metakognitif akan memiliki pengetahuan tentang bagaimana berpikir dan mampu mengontrol pembelajarannya. Menurut Permendikbud (2016) pengetahuan metakognitif adalah pengetahuan tentang kekuatan dan kelemahan diri sendiri dan menggunakannya dalam mempelajari pengetahuan teknis, detail, spesifik, kompleks, kontekstual dan kondisional berkenaan dengan ilmu pengetahuan, teknologi, seni, dan budaya terkait dengan masyarakat. Menurut Livingston (2003) metakognitif dapat juga dikatakan sebagai "thinking about thinking" berpikir tentang proses berpikir itu sendiri. Menurut Flavell (1979) metakognitif terdiri dari pengetahuan metakognitif (metacognitive knowledge) dan pengalaman metakognitif atau regulasi (metacognitive experiences or regulation. Selanjutnya Schraw and Dennison (1994) mengungkapkan pengetahuan metakognitif meliputi tiga proses pengetahuan deklaratif (declarative knowledge), pengetahuan prosedural (procedural knowledge), and pengetahuan kondisional (conditional knowledge) dan pengalaman metakognitif atau peraturan (metacognitive experiences or regulation) menjadi lima komponen proses yaitu perencanaan (including planing), management informasi (information management strategies), pemahaman pemantauan (comprehention monitoring), strategi tindakan (debugging strategies), dan evaluasi (evaluating).

Jadi, metakognitif adalah kemampuan berpikir tingkat tinggi di mana yang menjadi objek berpikirnya adalah proses berpikir yang terjadi pada diri sendiri berpikir tentang pengetahuan, dan berpikir tentang bagaimana memperolehnya yang dilakukan secara sadar oleh diri peserta didik sendiri selama proses pembelajaran.

Kesadaran metakognitif dimaknai sebagai kesadaran seseorang terhadap kemampuan metakognitif yang dimiliki, kegiatannya seperti perencanaan bagaimana startegi belajar yang tepat, pemantauan terhadap pemahaman, dan mengevaluasi proses pembelajaran sendiri (Schraw and Desnnison (1994). Dengan adanya kesadaran metakognitif, peserta didik akan memahami pengetahuan yang dimilikinya, dan dengan pengetahuan tersebut peserta didik dapat menyelesaikan suatu permasalahan dengan tepat. Kesadaran metakognitif ini sangatlah diperlukan dalam menyelesaikan suatu permasalahan agar 
penggunaan kemampuan kognitif menjadi lebih efektif dan efisien (Wilson \& Conyers, 2016).

Peserta didik yang menyadari kemampuan metakognitifnya akan belajar berdasarkan kemampuan kognitifnya, memahami cara berfikirnya memahami proses kognitif yang dilakukanya kemudian dapat mengetahui kelemahanya dalam belajar dan bisa melakukan perbaikan - perbaikan dalam pembelajaran. Hal ini sesuai dengan yang di katakan oleh Garner \& Alexander (1989) dalam Schraw and Dennison (1994) peserta didik yang sadar akan kemampuan metakognitifnya lebih strategis dan berkinerja lebih baik dari pada peserta didik yang tidak sadar. Pada proses pembelajaran sering kali kita beranggapan bahwa perkembangan kemampuan kognitif sebagai penentu dari kecerdasan intelektual seseorang karena kemampuan kognitif terus menerus berkembang diiringi dengan proses pendidikan yang berkelanjutan. Setiap individu pada dasarnya sudah memiliki potensi kemampuan metakognitif, hal ini dapat diketahui karena setiap individu sudah terbiasa berfikir tentang apa yang dipikirkannya dan apa yang akan dan telah dilakukannya. Begitu pula halnya dengan peserta didik, saat mengikuti kegiatan belajar mengajar, begitu peserta didik mendengar penjelasan tentang materi yang akan dipelajari, otomatis sebagian peserta didik akan mulai berfikir tentang apa yang akan dipelajarinya.

Adanya kesadaran metakognitif dalam konteks pembelajaran, maka peseserta didik akan mengetahui bagaimana cara untuk belajar, mengetahui kemampuan, modalitas belajar yang dimiliki dan mengetahui strategi belajar terbaik untuk belajar efektif. Kesadaran metakognitif dapat digunakan seseorang untuk memantau kemampuan kognisinya sejauh mana memahami suatu masalah dalam belajar. Pada saat kegiatan pembelajaran berlangsung akan banyak timbul pertanyaan-pertanyaan yang ada dalam benak peserta didik, yang kadang mereka bingung atau sulit mengungkapkannya.

Pembelajaran yang dilakukan selama ini cenderung hanya menekankan pada penguasaan konsep kognitif yang dijaring dengan tes tulis objektif. Sehingga peserta didik belajar cendung menghafal, dan ketika dihadapkan dengan suatu permasalahan peserta didik mengalami kesulitan. Berdasarkan hasil wawancara yang dilakukan dengan guru fisika kelas X MIA di SMA Islam Al-Falah Jambi belum pernah dievaluasi tentang metakognitif. Soal ujian dan tugas yang diberikan guru umumnya sebatas aspek kognitif sedangkan ruang untuk metakognitif kurang diberdayakan. Kemudian, data mengenai kesadaran metakognitif peserta didik juga belum diketahui. Selain itu pada kelas X MIA SMA Islam Al-Falah Jambi belum pernah di identifikasi kesadaran metakognitif peserta didik.

Berdasarkan paparan di atas, informasi tentang kesadaran metakognitif sangat penting untuk diketahui karena merepresentasikan kemampuan peserta didik untuk mengelola / mengatur kemampuan kognitifnya. Hal ini sesuai dengan yang dikatakan oleh Nurmalasari, Winarso, and Nurhayati (2015) bahwa semakin baik kemampuan metakognitif yang dimiliki peserta didik maka semakin baik hasil belajar yang diperoleh. Kesadaran metakognitif sangat penting untuk proses pembelajaran karena merupakan sesuatu yang harus dilakukan sebelum, selama, dan setelah pengajaran. Mengingat pentingnya metakognitif dalam menunjang keberhasilan belajar serta perlu diberdayakannya kemampuan metakognitif ini maka langkah pertama yang dilakukan adalah mengidentifikasi kesadaran metakognitif peserta didik. Berdasarkan beberapa pernyataan di atas secara teoretik metakognitif merupakan dimensi pengetahuan, namun kesadaran metakognitif dapat mengukur dari aspek pengetahuan metakognitif dan proses mendapatkan pengetahuan melalui pengalaman atau regulasi kognitif

\section{METODE PENELITIAN}

Penelitian menggunakan rancangan penelitian MIX Method dengan desain sequential eksplanatori. Penelitian dilakukan di SMA Al Falah Jambi pada bukan september s.d November 2018. Populasi penelitian adalah seluruh peserta didik kelas X sejumlah 90 orang. Teknik sampel yang digunakan dalam penelitian ini adalah teknik purposive sampling. Sampel yang di gunakan sebnyak 30 orang peserta didik di berikan angket Metacognitive Awareness Inventory (MAI) untuk mengidentifikasi kesadaran Metakognitif yang mereka miliki dan sebanyak 6 orang peserta didik yang di 
wawancarai untuk menjelaskan hasil angket peserta didik.

\section{HASIL DAN PEMBAHASAN}

Hasil penelitian terhadap kesadaran metakognitif peserta didik kelas X MIA di SMA Islam Al- Falah Jambi yang ditinjau dari kategori Pengetahuan metakognitif dan regulasi kognisi adalah sebagai berikut :

\section{Pengetahuan Metakognitif}

Pada indikator pengetahuan metakognitif terdiri dari pengetahuan deklaratif, pengetahuan prosedural dan pengetahuan kondisional yang dideskrifsikan sebagai berikut.

\section{A. Pengetahuan Deklaratif (Declarative Knowledge)}

Setelah di lakukan penyebaran angket Metacognitive Awareness Inventory (MAI) di dapatkan hasil angket sebagai berikut :

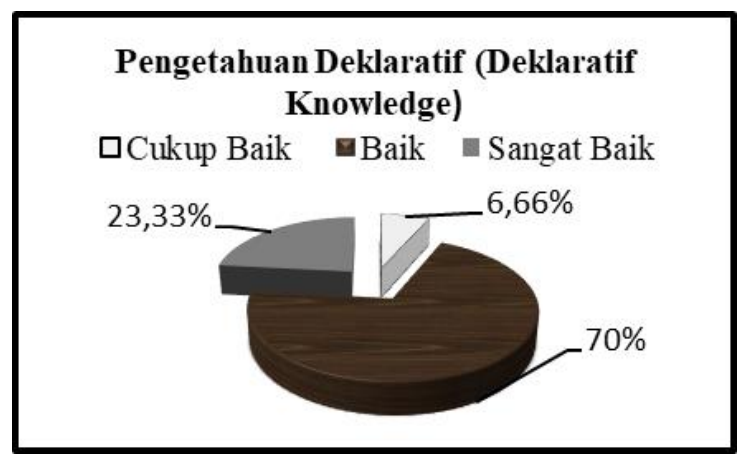

Gambar 1. Diagram Pengetahuan Deklaratif (Deklaratif Knowledge)

Berdasarkan gambar 1 di atas dapat diketahui bahwa untuk kategori peserta didik tidak baik terhadap pengetahuan deklaratif (Deklaratif Knowledge) memiliki presentase 0\%, sedangkan untuk kategori cukup baik memiliki presentase $6,66 \%$, adapun untuk kategori baik memiliki presentase $70 \%$ dan untuk kategori peserta didik sangat baik memiliki presentase 23,33\%. Brdasarkan hasil angket dan hasil wawancara pengetahuan deklaratif (declarative knowledge) peserta didik kelas X MIA SMA Islam Al- Falah Jambi dapat di kategorikan baik. Peserta didik yang baik terhadap pengetahuan deklaratif (declarative knowledge) dapat memahami kekuatan dan kelemahanya kemudian mengetahui bagaimana cara menaggulangi kelemahanya tersebut. Hal ini sejalan dengan hasil penelitian yang dilakukan oleh Sumadyo and Purwantini (2018) peserta didik dengan pengetahuan deklaratif (declarative knowledge) yang tinggi akan mengetahui kelebihan dan kekurangannya. Dengan mengetahui kekurangan pada suatu mata pelajaran, misalnya, seorang peserta didik dapat mengantisipasi kegagalan dengan mempersiapkan diri ketika menghadapi ujian mata pelajaran tersebut.

\section{B. Pengetahuan prosedural (Procedural Knowledge)}

Setelah di lakukan penyebaran angket Metacognitive Awareness Inventory (MAI) di dapatkan hasil angket sebagai berikut :

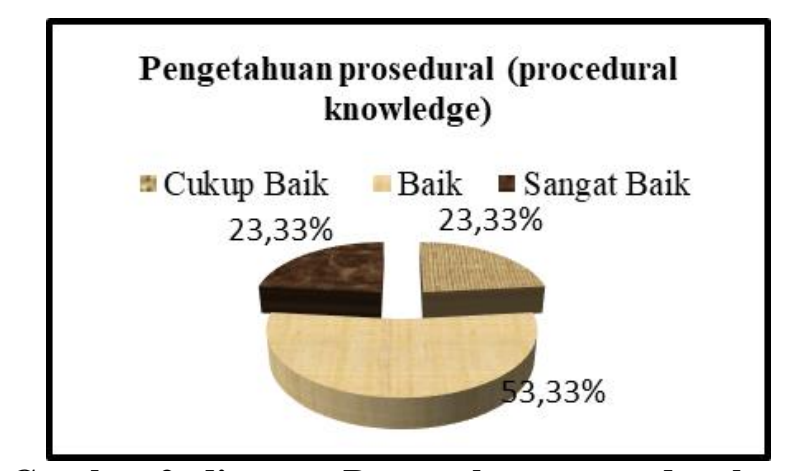

Gambar 2. diagram Pengetahuan prosedural (procedural knowledge)

Berdasarkan gambar 2 di atas dapat diketahui bahwa untuk kategori peserta didik tidak baik terhadap pengetahuan prosedural (procedural knowledge) memiliki presentase 0\%, sedangkan untuk kategori peserta didik cukup memiliki presentase $23,33 \%$, adapun untuk kategori baik memeliki presentase 53,33\% dan untuk kategori sangat baik memiliki presentase $23,33 \%$.

Berdasarkan hasil angket dan hasil wawancara pengetahuan prosedural (procedural knowledge) peserta didik kelas X MIA SMA Islam Al- Falah Jambi dapat di kategorikan baik. Peserta didik yang baik terhadap pengetahuan prosedural (procedural knowledge) dapat memahami strategi belajar yang di gunakan dan ia dapat memahami strategi belajar yang dia gunakan dan ia bisa secara otomatis menggunakan strategi belajar yang bermanfaat dan dapat menggunakan dan memilih prosedur yang sesuai dengan benar pada saat mereka 
menyelesaikan suatu masalah. Hal ini sesuai dengan yang di katakan oleh Haryanti (2013 ) bahwa "peserta didik dikatakan dapat mempunyai pengetahuan prosedural dalam pembelajaran matematika ketika mereka dapat memilih dan menerapkan prosedur yang sesuai dengan benar pada saat mereka menyelesaikan suatu masalah".

\section{Pengetahuan Kondisional (Conditional Knowledge)}

Setelah di lakukan penyebaran angket Metacognitive Awareness Inventory (MAI) di dapatkan hasil angket sebagai berikut :

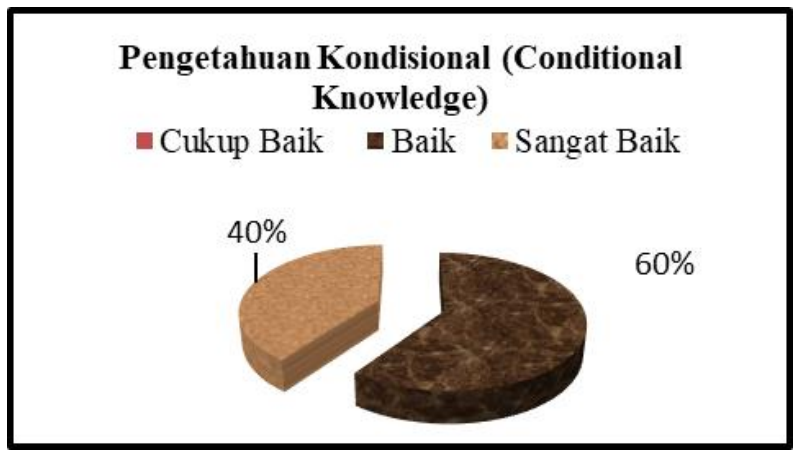

Gambar 3. Diagram Pengetahuan Kondisional (Conditional Knowledge)

Berdasarkan gambar 3 di atas dapat di ketahui bahwa peserta didik tidak baik dan cukup baik memiliki presentase $0 \%$. Sedangkan untuk kategori baik memiliki presentase $60 \%$ dan untuk kategori sangat baik memiliki presentase $40 \%$

Berdasarkan hasil angket dan hasil wawancara pengetahuan kondisional (conditional knowledge), peserta didik kelas X MIA SMA Islam Al- Falah Jambi dapat di kategorikan baik. Peserta didik yang baik terhadap pengetahuan kondisional (conditional knowledge), dalam belajar peserta didik menyadari kapan suatu strategi yang baik di gunakan dan kapan strategi tersebut tidak di gunakan dan ia juga mengetahui bahwa mengapa suatu strategi tesebut lebih baik digunakan dari pada strategi yang lain. Hal ini sesuai dengan yang di katakan oleh Tanti, Widada, and Haji (2018) pengetahuan kondisional adalah pengetahuan tentang kapan harus menggunakan suatu prosedur, keterampilan, atau strategi dan kapan tidak menggunakannya, mengapa prosedur dapat digunakan dan dalam kondisi apa, serta mengapa suatu prosedur tersebut lebih baik dari yang lainnya.

\section{Regulasi Kognisi}

Pada indikator regulasi kognisi terdiri dari perencanaan, strategi mengelola informasi, pemantauan terhadap pemahaman,strategi perbaikan dan evaluasi yang dideskripsikan sebagai berikut

\section{A. Perencanaan (Planning)}

Setelah di lakukan penyebaran angket Metacognitive Awareness Inventory (MAI) di dapatkan hasil angket sebagai berikut :

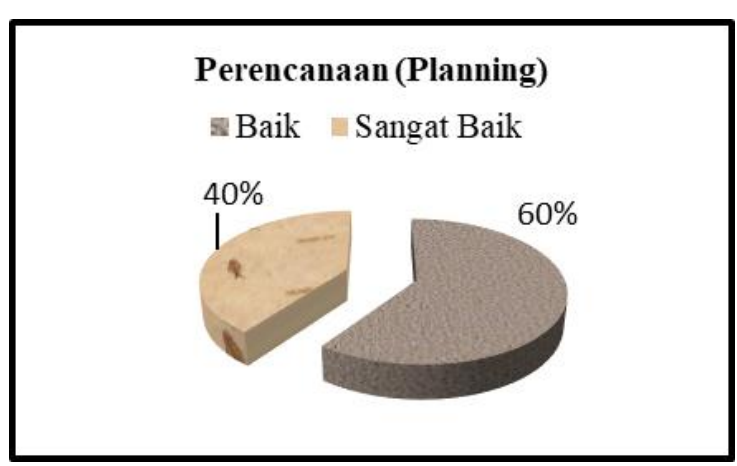
Gambar 4 Diagram Kegiatan Perencanaan
(Planning)

Berdasarkan gambar 4 di atas diagram perencanaan (planing) di dapatkan informasi bahwa untuk kategori peserta didik tidak baik dan cukup baik memiliki presentase $0 \%$. Sedangkan untuk kategori baik memiliki presentase $60 \%$ dan untuk kategori sangat baik memiliki presentase $40 \%$.

Berdasarkan hasil angket dan hasil wawancara terhadap kegiatan perencanaan (planing) peserta didik kelas X MIA SMA Islam Al- Falah Jambi dapat di kategorikan baik. Peserta didik yang baik terhadap kegiatan perencanaan (planing), dalam belajar peserta didik memiliki beberapa cara untuk menyelesaikan masalah dan memilih yang terbaik seperti membaca perintah dengan hatihati sebelum mulai mengerjakan tugas, kuis, atau ujian dan mampu mengatur waktu dengan baik untuk mencapai tujuan dalam belajar. Peserta didik ini mempunyai target tertentu saat mengerjakan tugas misalnya dalam waktu 15 menit tugas ini sudah harus selesai. Kegiatan perencanaan mencakup pemilihan strategi yang 
tepat dan alokasi sumber-sumber belajar yang diperlukan hal ini dapat menunjang keberhasilan peserta didik dalam belajar. Hal ini sesuai dengan yamg dikatakan Sumampouw (2011) bahwa aktivitas - aktivitas perencanaan seperti menunjukan tujuan dan analisis tugas membantu mengaktivasi pengetahuan yang relevan sehingga mempermudah pengorganisasian dan pemahaman materi pembelajaran.

\section{B. Indikator Strategi Mengelola Informasi (Information Management Strategies)}

Setelah di lakukan penyebaran angket Metacognitive Awareness Inventory (MAI) di dapatkan hasil angket sebagai berikut :

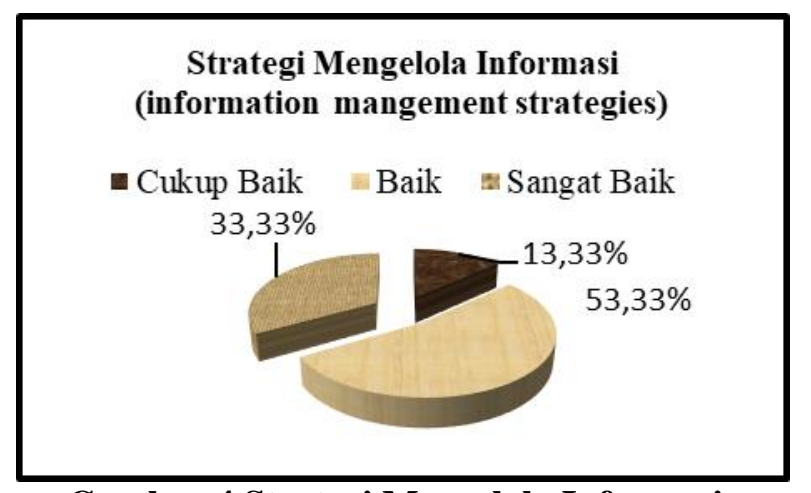

Gambar 4 Strategi Mengelola Informasi
(information mangement strategies)

Berdasarkan gambar 4 diatas dapat di ketahui bahwa untuk kategori peserta didik tidak baik memiliki presentase $0 \%$, sedangkan untuk kategori cukup baik memiliki presentase 13,33\%. Adapun untuk kategori baik memiliki presentase $53,33 \%$ dan untuk kategori sangat baik memiliki presentase $33,33 \%$.

Berdasarkan hasil angket dan hasil wawancara kegiatan strategi mengelola informasi (information mangement strategies) peserta didik kelas X MIA SMA Islam Al- Falah Jambi dapat di kategorikan baik. peserta didik yang baik terhadap kegiatan strategi mengelola informasi (information mangeent strategies), dalam belajar fisika peserta didik memfokuskan perhatian pada informasi penting misalnya konsep suatu materi dalam fisika contohnya pada hukum ohm. Ketika menemukan informasi yang penting dalam sebuah tulisan, ia akan memperlambat bacaannya karena ingin memahami maksud dari bacaan tersebut dan belajar dengan membuat langkah - langkah dalam menemukan informasi yang baru. Hal ini sesuai dengan yang dikatakan Paipinan (2015) bahwa pada kegiatan strategi mengelola informasi peserta didik menyadari untuk memperhatikan dengan seksama dan memusatkan perhatian pada informasi yang penting, menyadari bahwa perlu membuat gambar dan menyusun masalah dengan kata kata sendiri untuk memudahkan memahami masalah, mengetahui bahwa masalah yang dihadapi berkaitan dengan sesuatu yang diketahui

\section{Pemantauan Terhadap Pemahaman (Comprehension Monitoring)}

Setelah di lakukan penyebaran angket Metacognitive Awareness Inventory (MAI) di dapatkan hasil angket sebagai berikut :

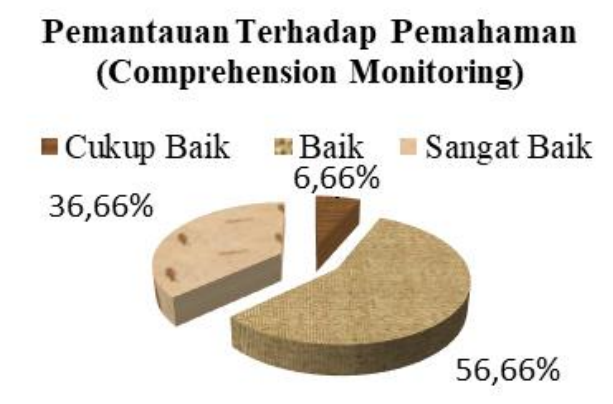

Gambar 6 diagram Pemantauan Terhadap Pemahaman (Comprehension Monitoring)

$\begin{array}{lcrr}\quad \text { Berdasarkan } & \begin{array}{c}\text { gambar } \\ \text { pemantauan }\end{array} & \begin{array}{r}\text { diagram } \\ \text { terhadap }\end{array} & \text { pemahaman } \\ \text { (Comprehension } & \text { Monitoring) } & \text { di } & \text { dapatkan }\end{array}$ informasi bahwa untuk kategori peserta didik tidak baik memiliki presentase $0 \%$, sedangkan untuk kategori cukup memiliki presentase $6,66 \%$. Adapun untuk kategori baik memiliki presentase $56,66 \%$ dan untuk kategori sangat baik memiliki presentase $36,66 \%$.

Berdasarkan hasil angket dan hasil wawancara kegiatan pemantauan terhadap pemahaman (comprehension monitoring) peserta didik kelas X MIA SMA Islam Al- Falah Jambi dapat di kategorikan baik. Peserta didik yang baik terhadap kegiatan pemantauan terhadap pemahaman (Comprehension Monitoring), dalam belajar fisika peserta didik ini akan mempertimbangkan beberapa alternatif dari sebuah permasalahan sebelum ia menjawabnya, 
peserta didik ini pada waktu tertentu misalnya setelah shalat subuh ia mempelajari ulang suatu materi untuk pemahaman yang lebih dalam. Peserta didik akan bertanya pada diirnya senidri secara berkala apakah ia telah telah mencapai tujuan-tujuan dalam belajar. Kemudian setelah belajar ia akan berhenti sejenak secara teratur untuk mengecek pemahaman mengenai materi yang sedang di pelajari. Hal ini sesuai dengan Sumampouw (2011) aktivitas - aktivitas pemantauan meliputi perhatian seseorang ketika ia membaca, dan membuat pertanyaan atau pengujian diri. Aktivitas-aktivitas ini membantu peserta didik dalam memahami materi dan mengintegrasikannya dengan pengetahuan awal.

\section{Strategi Perbaikan (Debugging Strategies)}

Setelah di lakukan penyebaran angket Metacognitive Awareness Inventory (MAI) di dapatkan hasil angket sebagai berikut:

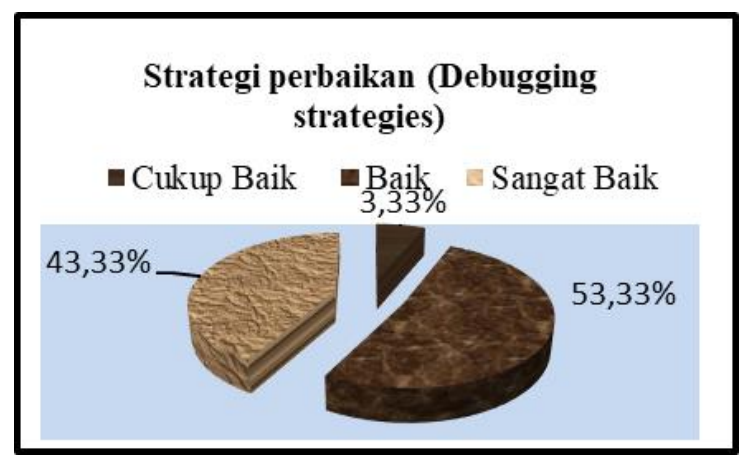

Gambar 7. diagram Strategi perbaikan (Debugging strategies)

Berdasarkan gambar 7 di atas dapat diketahui bahwa bahwa untuk kategori peserta didik tidak baik memiliki presentase $0 \%$, sedangkan untuk kategori cukup baik memiliki presentase $3,33 \%$. Adapun untuk kategori baik memiliki presentase 53,33\%.dan untuk kategori sangat baik memiliki presentase 43,33\% .

Berdasarkan hasil angket dan hasil wawancara kegiatan strategi perbaikan (Debugging Strategies) peserta didik kelas $\mathrm{X}$ MIA SMA Islam Al- Falah Jambi dapat di kategorikan baik. Peserta didik yang baik terhadap kegiatan strategi perbaikan (Debugging Strategies), dalam belajar fisika peserta didik akan meminta bantuan orang lain ketika ia tidak mengerti mengenai materi fisika yang ia pelajari misalnya bertanya pada guru, atau temanya.
Kemudian ketika gagal dalam memahami sebuah materi fisika, ia akan mengubah strategi belajar yang biasa ia gunakan sebelumnya. Peserta didik ini akan membaca ulang suatu bacaan ketika ia bingung dan tidak paham apa maksud dari bacaan tersebut. Kegiatan ini dapat membantu peserta didik dalam menyelesaikan suatu permasalahan untuk menunjang keberhasilan belajar. Hal ini sesuai dengan Sumampouw (2011) bahwa "aktivitas-aktivitas pengaturan meliputi penyesuaian dan perbaikan aktivitasaktivitas kognitif peserta didik. Aktivitasaktivitas ini membantu peningkatan prestasi dengan cara mengawasi dan mengoreksi perilakunya pada saat ia menyelesaikan tugas".

\section{E. Evaluasi (evaluation)}

Setelah di lakukan penyebaran angket Metacognitive Awareness Inventory (MAI) di dapatkan hasil angket sebagai berikut:

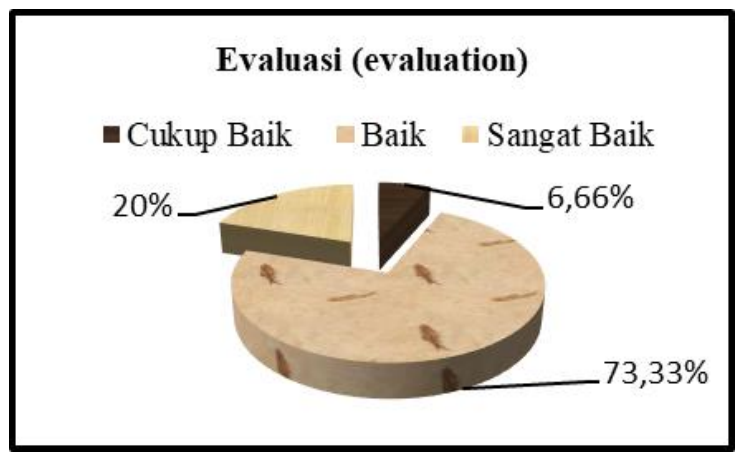

Gambar 8 diagram evaluasi (evaluation)

Berdasarkan gambar 8 di atas dapat di ketahui bahwa untuk kategori peserta didik tidak baik terhadap kegiatan evaluasi (evaluation) memiliki presentase $0 \%$, sedangkan untuk kategori cukup baik memiliki presentase $6,66 \%$. Adapun untuk kategori baik memiliki presentase $20 \%$ dan untuk kategori sangat baik memiliki presentase $73,33 \%$.

Berdasarkan hasil angket dan hasil wawancara kegiatan evaluasi (evaluation) peserta didik pada kelas X MIA SMA Islam AlFalah Jambi dapat di kategorikan baik. Peserta didik yang baik terhadap terhadap kegiatan evaluasi (evaluation), dalam belajar peserta didik memahami cara mengevaluasi hasil belajarnya sendiri yaitu dengan cara mengevaluasi tujuan belajar yang ia targetkan sebelumnya, target yang ingin di capai oleh peserta didik ini adalah untuk 
dapat memahami materi dan mengaplikasikanya untuk menyelesaikan suatu permasalahan. Peserta didik ini juga kan menggunakaan strategi yang belajar yang berbeda beda tergantung situasi misalnya pada saat mempelajari materi yang bersifat hafalan ia kan mencoba membuat catatan - catatan kecil supaya mudah untuk memahami, dan jika memahami suatu materi yang bersifat pemahaman bukan hafalan ia akan membaca dengan hati - hati. Hal ini sesuai dengan Cohors-Fresenborg dan Kaune (2007) dalam Nulhakim (2013) Pada proses ini peserta didik membuat refleksi untuk mengetahui bagaimana suatu kemahiran, nilai dan suatu pengetahuan yang dikuasai oleh peserta didik tersebut. Mengapa peserta didik tersebut mudah atau sulit untuk menguasainya, dan ap tindakan atau perbaikan yang harus dilakukan.

\section{KESIMPULAN}

Kesadaran metakognitif peserta didik kelas $X$ MIA SMA Islam Al- Falah Jambi secara umum dikategorikan baik yang terlihat berdasarkan indikator kesadaran metakognitif yang di atas presentase lima puluh persen. Hal ini menunjukkan bahwa peserta didik kelas X MIA SMA Islam Al- Falah Jambi dapat mengetahui tentang diri sebagai pelajar berdasarkan faktorfaktor yang berdampak pada kinerja, pengetahuan tentang strategi, dan pengetahuan tentang kapan dan mengapa menggunakan strategi yang paling tepat dan mampu menanggulangi kelemahan atau kekuranganya dalam belajar Fisika. Hasil tersebut dapat memperkecil kesalahan peserta didik dalam belajar dan dapat menyusun strategi yang tepat untuk menyelesaikan permasalahan yang dihadapinya dalam pembelajaran fisika.

\section{DAFTAR PUSTAKA}

Creswell, J. (2015). Riset Pendidikan: Perencanaan, Pelaksanaan, Dan Evaluasi Riset Kualitatif \& Kuantitatif. Yogyakarta: Pustaka Pelajar.

Flavell, J. H. (1979). Metacognition And Cognitive Monitoring: A New Area Of Cognitive-Developmental Inquiry. American Psychologist, 34(10), 906.
Haryanti, D. (2013 ). Memperbaiki Pengetahuan Dan Kemampuan Prosedural Siswa Melalui Metode Penugasan Berbasis Kesalahan. Jurnal Pendidikan Dan Pembelajaran, 2 (2).

Indarini, E., Sadono, T., \& Onate, M. E. (2013). Pengetahuan Metakognitif Untuk Pendidik Dan Peserta Didik. Satya Widya, 29(1), 40-46.

Iskandar, S. M. (2016). Pendekatan Keterampilan Metakognitif Dalam Pembelajaran Sains Di Kelas. Erudio (Journal Of Educational Innovation), 2(2), 13-20.

Kadir, K. (2017). Meningkatan Metakognisi Siswa Dalam Pembelajaran Matematika Melalui Asesmen Kinerja Berbasis Masalah Dan Model Pembelajaran. Edukasi: Jurnal Penelitian Pendidikan Agama Dan Keagamaan, 7(3).

Livingston, J. A. (2003). Metacognition: An Overview.

Lockl, K., \& Schneider, W. (2007). Knowledge About The Mind: Links Between Theory Of Mind And Later Metamemory. Child Development, 78(1), 148-167.

Niedringhaus, K. L. (2010). Teaching Better Research Skills By Teaching Metacognitive Ability. Perspectives: Teaching Legal Research And Writing, 18(2), 113-118.

Nulhakim, L. (2013). Analisis Keterampilan Metakognitif Siswa Yang Dikembangkan Melalui Pembelajaran Berbasis Masalah Pada Materi Kelarutan Dan Hasil Kali Kelarutan. Universitas Pendidikan Indonesia.

Nurmalasari, L. R., Winarso, W., \& Nurhayati, E. (2015). Pengaruh Kemampuan Metakognisi Terhadap Hasil Belajar Matematika Di Smp Negeri 2 Leuwimunding Kabupaten Majalengka. Nusantara Of Researc, 02(02).

Paipinan, M. (2015). Profil Metakognisi Mahasiswa Calon Guru Matematikadalam Menyelesaikan Masalah Terbuka Geometri Ditinjau Dari 
Perbedaan Gender. Jurnal Ilmiah Matematika Dan Pembelajarannya, 1(1).

Permendikbud, L. (2016). Peraturan Menteri Pendidikan Dan Kebudayaan Republik Indonesia Nomor 20 Tahun 2016 Tentang Standar Kompetensi Lulusan Pendidikan Dasar Dan Menengah. Jakarta: Menteri Pendidikan Nasional.

Pujiank, S., Jamaluddin, J., \& Hadiprayitno, G. (2016). Kemampuan Metakognisi Mahasiswa Program Studi Pendidikan Biologi Fkip Universitas Mataram. Jurnal Pendidikan: Teori, Penelitian, Dan Pengembangan, 1(10).

Rahman, S., \& Arul, P. J. (2006). Hubungan Antara Kesedaran Metakognisi, Motivasi Dan Pencapaian Akademik Pelajar Universiti. Jurnal Pendidikan Malaysia (Malaysian Journal Of Education), 31, 21-39.

Romli, M. (2012). Strategi Membangun Metakognisi Siswa Sma Dalam Pemecahan Masalah Matematika. Aksioma: Jurnal Matematika Dan Pendidikan Matematika, 1(2/Septembe).

Saripudin, A. (2007). Metakognisi Dan Peran Serta Implikasinya Bagi Pembelajaran Membaca. Jurnal Lingua, Bahasa Dan Sastra Indonesia, 8(2), 183-191.

Schraw, G., \& Dennison, R. (1994). Assessing Meta-Cognitive Awareness. Contemporary Educa-Tional Psychology Development of The Comprehensive Learning, 19, 460-475.
Sumadyo, M., \& Purwantini, L. (2018). Penilaian Kemampuan Metakognitif Siswa Sma Dengan Menggunakan Algoritma K-Means. Paper Presented At The Prosiding Seminar Nasional Energi \& Teknologi (Sinergi).

Sumampouw, H. M. (2011). Keterampilan Metakognitif Dan Berpikir Tingkat Tinggi Dalam Pembelajaran Genetika (Artikulasi Konsep Dan Verifikasi Empiris). Bioedukasi: Jurnal Pendidikan Biologi, 4(2), 23-39.

Tamsyani, W. (2016). Pengaruh Model Pembelajaran Dan Kesadaran Metakognitif Terhadap Hasil Belajar Peserta Didik Sma Dalam Materi Pokok Asam Basa. Journal of Educational Science And Technology (Est), 2(1), 1025.

Tanti, N., Widada, W., \& Haji, S. (2018). Metakognisi Siswa Dalam Pemecahan Masalah Matematika Siswa Sma Dalam Pembelajaran Matematika Berorientasi Etnomatematika Rejang Lebong. Jurnal Pendidikan Matematika Raflesia, 3(1).

Untu, Z., Yuwono, I., Parta, I. N., \& Sisworo, S. (2018). Kesalahan Guru Dalam Pembelajaran Matematika Materi Bangun Datar Di Tinjuau Dari Pengetahuan Deklaratif. Jurnal Pendidik Indonesia (Jpin), 1(1).

Wilson, D. D., \& Conyers, M. (2016). Teaching Students To Drive Their Brains: Metacognitive Strategies, Activities, And Lesson Ideas. Usa: Ascd. 